\title{
Evaluation of some Control Methods of Weeds and Fungal Soil-Borne Diseases on Cumin and its Productivity
}

\section{Abdallah, M.A ${ }^{1}$; Hassanin, M.M.H. ${ }^{2}$ and Hassanein,} A.M.A. ${ }^{3}$

1- Medicinal and Aromatic Plants Research Department, Horticulture Research Institute, Agricultural Research Center, Giza, Egypt.

2- Plant Pathology Research Institute, Agricultural Research Center, Giza, Egypt.

3- Weed Research Central Laboratory, Agricultural Research

Center, Giza, Egypt.

Cumin plants infected with root rot and wilt diseases were collected $C$ from different locations of Behira, Ismailia and Minia governorates, Egypt. Many fungal species belonging to the genera Fusarium, Macrophomina, Rhizoctonia and Pythium were isolated from the infected plants. The results indicated that $F$. oxysporum recorded the highest frequency among the isolated fungi, followed by $R$. solani, F. solani, M. phaseolina and Pythium sp. The effect of various concentrations of marjoram and peppermint essential oils on the mycelial growth of the isolated fungi was tested in-vitro. Marjoram and peppermint oils completely inhibited the growth of $F$. oxysporum, $F$. solani, $R$. solani and Pythium sp. at the concentration $5 \mathrm{ml} / \mathrm{L}$. Field experiments were conducted at the Experi. Farm. of Agric. Res. Stat., Malawy, Minia Governorate, Egypt, during two successive seasons (2017/2018 and 2018/2019) to study the effect of different weed control treatments (hoeing, black polyethylene mulch, clover cover crop, unweeded control) on weed biomass. The results indicated that all weed control treatments significantly decreased the dry weight of grassy weeds, broad-leaved weeds and total weeds 70 days after sowing as compared to the unweeded control. Moreover, the effects of different weed control treatments and seed treatment with the biocides (Plant Guard and Rhizo-N) as well as the essential oils of peppermint and marjoram on the disease incidence, and some yield parameters of cumin plants were evaluated under field conditions. The results indicated that plastic mulch was the most effective in reducing wilt incidence as well as increasing cumin yield, while the unweeded plots had the highest disease incidence and the lowest yield. Furthermore, the application of the biocide Rhizo-N and marjoram essential oil seed dressing $(5 \mathrm{ml} / \mathrm{L})$ reduced the incidence of wilt and significantly increased seed yield. Thus, it could be suggested any of the biocide Rhizo-N or marjoram essential oil can be formulated to be used for controlling cumin wilt under field 
conditions. Moreover, integration of these methods could provide an approach for the management of the disease in infested fields more effectively.

Keywords: Cuminum cyminum, plastic mulch, cover crop, seed treatment, biocides, essential oils

Cumin (Cuminum cyminum L.) is an annual plant of the Apiaceae family. Cumin is used in folk medicine as a carminative for stomach disorders, diarrhea, and colic (Parthasarathy et al., 2008).Cumin seeds are used as a spice for flavoring soups, sauces, pickles and for seasoning breads and cakes (Farrell et al., 1985). The seeds contain 2-5\% essential oil, the principal constituent of which is cuminaldehyde (Duke, 2002). The cultivated area of cumin in Egypt reached about 5448 feddan during 2010 growing season and declined to 3489 and 1941 feddan during 2011 and 2012 growing seasons, respectively (Hassan et al., 2014). The decline in the cultivated area with cumin during the last decade may be due to wilting the plants in the latter stages of the plant life, which affects the quantity of the seed yield.

Fusarium wilt caused by Fusarium oxysporum f. sp. cumini is a destructive disease limiting cumin productivity (Dange, 1995; Khare et al., 2014 and Ghoneem et al., 2019). The disease occurs at all stages of crop growth. The leaves of infected plants drop down, the roots exhibit browning of vascular region when split open and fruiting do not occur. The pathogen is internally seed borne as well as soil borne (Khare et al., 2014). Root-rot of cumin is caused by six species of Fusarium, i.e. F. oxysporum, F. solani, F. monileforme, F. dimerum, F.equiseti and F. lateritium. In China the root rot has been reported due to $F$. oxysporum, $F$. solani, Rhizoctonia sp. and an unidentified Deuteromycetes fungus (Shujuan et al., 2012). These diseases are usually common year after year. This may be due to inappropriate agricultural practices, lack of adequate resistance to these diseases.

Cumin is most vulnerable to weed competition at all stages of its growth due to its slow growth cycle and short stature. Chemical pesticides are the most effective means for controlling weeds and fungal diseases in cumin plants (Bhatnagar et al., 2013 and Birla et al., 2016). However, the excessive use of these chemicals has caused pollution to the environment and hazard effect on human health. Therefore, there is a need to develop alternative strategies for weed and disease management that reduce pesticide use in an integrated approach.

Mulching is one of the effective and safe methods to reduce pests, soil-borne diseases and weed infestation. Mulching involves covering the soil with a layer of material around the crop, which prevents light required for germination of small seeded weeds (Teasdale and Mohler, 2000). Mulches are generally inorganic (black polyethylene and geotextile mulches), organic (wood, bark, and leaves), or living (turf grass, rye, and clover) materials. Polyethylene mulch combined with marigold

Egypt. J. Phytopathol., Vol. 47, No. 2 (2019) 
intercropping and fungicide application has resulted in an effective control of early blight of tomato caused by Alternaria solani (Jambhulkar et al., 2012).

Living mulches are cover crops that are planted between the rows of a main crop and are maintained as a living ground cover during the growing of the main crop. Although living mulches are sometimes referred to as cover crops, they grow at least part of the time simultaneously with the crop. In addition to providing adequate cover to reduce soil erosion and increase soil water infiltration, legume living mulches improve soil nutrient status through addition of organic nitrogen via fixed atmospheric nitrogen which improves soil physical properties (Mohammadi et al., 2012).

Additionally, seed treatment with essential oils and bioagents such as Trichoderma harzianum and Bacillus subtilis have been realized as an effective alternative for Fusarium wilt management in cumin plants (Tawfik and Allam, 2004). Furthermore, Hashem et al. (2010) tested the effectiveness of some essential oils in the control of cumin root rot, of which the essential oils of cumin, basil and geranium showed the highest effectiveness in controlling the disease.

Therefore, the objective of this study was to assess the effect of black plastic mulch, clover cover crop and hoeing as weed control treatments on biomass of grassy weeds, broad-leaved weeds and total weeds. In addition, to assess the impact of weed control treatments, seed treatments with biocides and essential oils of peppermint and marjoram on the incidence of Fusarium wilt and crop parameters of cumin plants in Middle Egypt region to develop an integrated management strategy for the control of cumin wilt.

\section{Materials and Methods}

Isolation and identification of the associated fungi

Infected cumin plants showing wilt and root rot symptoms were collected from plantations of Beheira, Ismailia and Minia governorates during 2016/2017 growing season. These symptoms were yellowing, stunting, and dried shoots and wilt. Infected roots were thoroughly washed several times with tap water, then cut into small pieces and surface sterilized by immersing in $1 \%$ sodium hypochlorite for 2 minutes, washed several times with sterilized stilled water and dried between folds of sterilized filter papers. The surface sterilized pieces were then plated onto potato dextrose agar (PDA) medium in Petri-dishes. The plates were incubated at $27 \pm 1^{\circ} \mathrm{C}$ for 7 days. The growing fungi were purified using single spore or hyphal tip techniques. Fungi were identified depending on their morphological features according to the description of Booth (1971), Domsch et al. (1980) and Niternik and Vandler (1981) and the identification was confirmed by the staff member of Department of Mycology, Plant Disease Survey and Plant Pathology Research Institute, ARC, Giza, Egypt. Pure cultures on PDA slants were kept at low temperature $\left(5^{\circ} \mathrm{C}\right)$ for further studies. 
Pathogenicity test

Pathogenicity test was conducted to all the isolated soil fungi, i.e. Fusarium oxysporum, F. solani, Macrophomina phaseolina, Pythium sp. and Rhizoctonia solani. Sandy clay soil (1 sand: 1 clay) was sterilized by $5 \%$ formalin solution for one week, then left to dry for two weeks before use. Tested fungi were separately cultured on autoclaved sorghum grains medium (100 g sorghum $+100 \mathrm{ml}$ water), at $27 \pm 1^{\circ} \mathrm{C}$ for 15 days. Soil infestation with the isolated fungi was applied at the rate of $1 \% \mathrm{w} / \mathrm{w}$, which thoroughly mixed with the upper soil surface in plastic pots $(20 \mathrm{~cm}$ diameter). Pots were watered till saturation one week before sowing to enhance colonization of the fungi. Cumin seeds (cv. Balady) were surface sterilized using $0.1 \%$ sodium hypochlorite for one minute, then washed with sterilized distilled water and left to dry. Pots were sown with 20 seeds for each. All treatments were replicated three times. Disease incidence was recorded as percentages of pre-, postemergence damping-off and wilt 25, 45 and 90 days after sowing, respectively using the following formula (Waller et al., 2002).

$$
\text { Disease incidence } \%=\frac{\text { Number of infected plants }}{\text { Total number of planted seeds }} \times 100
$$

Fungi were re-isolated from the infected plants and compared with the original isolates.

Evaluation the effect of the essential oil emulsions on the mycelial growth of the tested fungi in vitro

Essential oils of marjoram and peppermint were obtained from Med. and Arom. Plants Res. Dept., Horticulture Research Institute, Agricultural Research Center, Giza, Egypt. The essential oil emulsions were prepared by adding $10 \mathrm{ml}$ of any of the two essential oils and $5 \mathrm{ml}$ of non-ionic surfactant Tween 80 slowly under gentle stirring until a homogeneous mixture was formed. Then, sterilized water $(85 \mathrm{ml})$ was added to reach the final mixture of each oil to $100 \mathrm{ml}$, to enhance distribution and complete incorporate the essential oils and then stirred using a magnetic stirrer for $30 \mathrm{~min}$. The efficacy of volatile substances in reducing the fungal growth was tested. Prepared emulsion of the essential oils of marjoram and peppermint were added to sterilized PDA flasks before solidification to obtain the proposed concentrations of $1,2,3,4$ and $5 \mathrm{ml} / \mathrm{L}$ medium. The bactericide (Chloramphenicol, $(0.1 \mathrm{mg} / \mathrm{L})$ was added to the medium to avoid bacterial contamination. Three plates $(9 \mathrm{~cm}$ in diam.) containing potato dextrose agar (PDA) medium were separately inoculated with discs (5-mm-diam.) taken from the edge of 7 days old culture of any of Fusarium oxysporum, F. solani, Macrophomina phaseolina, Pythium sp. and Rhizoctonia solani, isolated from cumin plants. Petri dishes were incubated at $25 \pm 2^{\circ} \mathrm{C}$. Percentages of fungal growth inhibitions were calculated when the fungal growth of the control plates (without treatments) completely covered the plates according to the formula suggested by Topps and Wain (1957) as follows:

Egypt. J. Phytopathol., Vol. 47, No. 2 (2019) 


$$
\% \text { Inhibition }=\frac{\mathrm{A}-\mathrm{B}}{\mathrm{A}} \times 100
$$

$\mathrm{A}=$ The linear growth $(\mathrm{cm})$ in control treatment.

$\mathrm{B}=$ The linear growth $(\mathrm{cm})$ of treated fungus.

\section{Field experiments}

Field experiments were carried out at the Experi. Farm of Agric. Res. Stat., Malawy, Minia governorate, Egypt during two successive seasons (2017/2018 and 2018/2019) to evaluate the effect of different weed control treatments (hoeing, black plastic mulch and cover crop), seed treatment with two commercial biocides (Plant Guard and Rhizo-N)and essential oil emulsions (peppermint and marjoram) on the disease incidence, and crop parameters of cumin plants. The layout of the experiment was a split plot design with three replicates for each treatment. The main plots were assigned to the weed control treatments and the sub plots were assigned to the seed treatment. The soil of the experimental site is classified as silty clay. The field was prepared and divided into plots. The plot size was $10.5 \mathrm{~m}^{2}(3.5 \mathrm{~m} \times 3 \mathrm{~m})$. Each plot consisted of five rows with $60 \mathrm{~cm}$ wide and $3.5 \mathrm{~m}$ long. Egyptian cumin seeds (Balady) were planted in hills $20 \mathrm{~cm}$ apart at the rate 3 seeds/hill. Seeds were planted on $1^{\text {st }}$ November in both seasons in a naturally infested field with the causal of cumin wilt. The recommended dose of nitrogen was applied at a rate of 250 $\mathrm{kg} / \mathrm{fed} \mathrm{using} \mathrm{ammonium} \mathrm{sulphate}(20.5 \% \mathrm{~N})$. Phosphorus was applied and mixed with the soil before sowing at a rate of $200 \mathrm{~kg} / \mathrm{fed}$ using calcium super phosphate $\left(15.5 \% \mathrm{P}_{2} \mathrm{O}_{5} \mathrm{P}\right)$. Potassium was applied at a rate of $50 \mathrm{~kg} / \mathrm{fed}$ using potassium sulphate $\left(48 \% \mathrm{~K}_{2} \mathrm{O}\right)$.

Treatments

Weed control treatments

Weed control treatments consisted of

1- Hoeing, three times.

2- Black polyethylene mulch of plastic films, 25-micron thickness was applied manually. Polyethylene sheets were covered on the rows. Holes were prepared on the plastic sheet in certain space of each plant. Cumin seeds were planted in the previously prepared holes.

3- Cover crop plots included clover (Trifolium alexandrinum) as the living mulch planted in mid-November at the rate of $30 \mathrm{~kg}$ clover seeds/fed. Clover seeds were planted after cumin initial growth on either side of the cumin rows. Clover plants were cut at 45 days after sowing. Clover was sown to compete with total weeds during the early stages of the growth of cumin plants and to improve soil nutrient status and physical properties, reduce soil erosion and increase soil water infiltration.

4- Un-weeded treatment as a control. 


\section{Seed treatment}

Cumin seeds were washed several times with sterilized water and soaked for 30 minutes in the solution or suspension of:

1- Biocide Plant Guard ( $1 \mathrm{ml}$ contains $30 \times 10^{6} \mathrm{CFU}$ of Trichoderma harzianum)

2- Biocide Rhizo-N ( $1 \mathrm{ml}$ contains $30 \times 10^{6} \mathrm{CFU}$ of Bacillus subtilis)

3- Marjoram essential oil emulsion

4- Peppermint essential oil emulsion

5- Water served as a control treatment

The biocides were applied at a concentration of $4 \mathrm{ml} / \mathrm{L}$ (obtained from the Central Lab. of Organic Agric., ARC), whereas essential oil emulsions were applied at a concentration of $5 \mathrm{ml} / \mathrm{L}$. According to a previous study (Hassanin et al., 2017), these concentrations had no adverse effects on seed germination. The soaked seeds were air dried at room temperature for one hour before sowing.

Data collection and analysis

\section{a- Weeds measurements}

After 70 days from sowing in both seasons, weed samples from one square meter area were randomly collected from each plot. Dry weight of broad-leaved, grassy weeds and total weeds were estimated and determined after drying in an oven at $70^{\circ} \mathrm{C}$ to constant weight $(\mathrm{g})$.

$b$ - Frequency percentage of the isolated fungi

$$
\begin{aligned}
& \% \text { Frequency }=\frac{\text { No. of fungal colonies for each isolated fungus }}{\text { Total No. of fungal colonies of the isolated fungi }} \times 100 \\
& \text { c-Disease incidence }
\end{aligned}
$$

The incidence of cumin wilt was determined 90 days after sowing and calculated by the following formula:

\section{$d$-Vegetative growth and yield traits}

$$
\text { Incidence of wilt }(\%)=\frac{\text { Number of infected plants }}{\text { Total number of plants }} \times 100
$$

Plant samples were randomly collected from all treatments 90 days after sowing. Plant height $(\mathrm{cm})$, number of branches/plant and number of umbels/plant were recorded during both seasons. At harvest, seed yield $(\mathrm{kg})$ of each plot was recorded and then converted to $\mathrm{kg} /$ feddan.

The collected data were statistically analyzed according to the method described by Snedecor and Cochran (1980). Least Significant Difference test was used for comparison between means of treatments.

Egypt. J. Phytopathol., Vol. 47, No. 2 (2019) 


\section{Results and Discussion}

Isolation and identification of the associated fungi

Fungi belonging to four fungal genera, i.e. Fusarium, Macrophomina, Rhizoctonia and Pythium were isolated from infected samples of cumin plants. Samples showing root rot and/or wilt symptoms were collected from different locations of South Tahrir district, El-kassasin and Malawy counties, representing Beheira, Ismailia and Minia governorates, respectively during 2016/2017growing season. Isolated fungi were purified and identified as: Fusarium oxysporum Schlecht, Fusarium solani (Mart.) Appel \& Wollenw, Macrophomina phaseolina (Tassi) Goid., Pythium sp. and Rhizoctonia solani Kuhn. Results in Table (1) indicate that $F$. oxysporum recorded the highest mean frequency of fungi isolated (39.19\%), followed by $R$. solani (24.93\%), F. solani (16.29\%), M. phaseolina $(13.08 \%)$ and Pythium sp. (6.51\%). Only $F$. oxysporum was isolated from wilted plants. On the other hand, the other fungi were isolated from cumin plants suffered from root rot. $F$. oxysporum was the most frequent isolated fungus in the three governorates followed by $F$. solani for Beheira and Minia governorates and $R$. solani for the three governorates. Fusarium solani was not isolated from Ismailia governorate and Pythium sp. was not isolated from Beheira and Minia governorates. The widespread of these diseases seem to be function of environmental factors. Minia governorate (Malawy county) is characterized by having a clay soil texture while Beheira governorate (South Tahrir district) and Ismailia governorate (ElKassasin county) are characterized by having a sandy soil texture. Fusarium spp. recorded the higher frequency as comparing with the other fungi isolated from the three governorates indicating their ability to survive in most soil types. Such finding goes in accordance with the data obtained by Hilal et al. (1993), Hassanin (2013) and Singh et al. (2017).

Table (1): Fungi isolated from infected cumin plants collected from different governorates during 2016/2017 growing season and their frequency.

\begin{tabular}{lccccc}
\hline \multirow{2}{*}{ Isolated fungi } & \multicolumn{4}{c}{$\%$ Frequency of fungi at governorate } & \multirow{2}{*}{ Symptoms } \\
\cline { 2 - 5 } & Beheira & Ismailia & Minia & Mean & \\
\hline Fusarium oxysporum & 40.73 & 33.14 & 43.70 & 39.19 & Wilt \\
F. solani & 25.00 & 00.00 & 23.87 & 16.29 & Root rot \\
Macrophomina phaseolina & 11.29 & 17.75 & 10.19 & 13.08 & Root rot \\
Rhizoctonia solani & 22.98 & 29.59 & 22.24 & 24.93 & Root rot \\
Pythium sp. & 00.00 & 19.53 & 00.00 & 06.51 & Root rot \\
\hline Total & 100.00 & 100.00 & 100.00 & 100.00 & - \\
\hline
\end{tabular}


Pathogenicity test

All tested fungi (Table 2) were found to be pathogenic to cumin plants with different percentages of pre- and post-emergence damping-off. The highest percentage $(40.0 \%)$ of pre-emergence damping-off was caused by M. phaseolina isolate No. (1). Meanwhile, $R$. solani isolate No. (1), F. oxysporum isolate No. (1) and $F$. solani isolate No. (1) recorded the highest percentages of post-emergence damping- off, being40.00, 33.33 and $26.67 \%$, respectively. On the other hand, symptoms of wilt caused by $F$. oxysporum appeared at 90 days after planting. $F$. oxysporum (1) isolated from Behiera governorate recorded the highest percentage of cumin wilt in the growing cumin plants $(26.67 \%)$. These results are similar to those reported by Hilal et al. (1993) and Nada et al. (2014).

Table (2): Percentages of pre- and post- emergence damping- off as well as wilt infection used by the tested fungi, 25,45 and 90 days after sowing, respectively, greenhouse experiment.

\begin{tabular}{|c|c|c|c|c|}
\hline \multirow[b]{2}{*}{ Tested fungi } & \multicolumn{2}{|c|}{ \% Damping-off } & \multirow{2}{*}{$\begin{array}{l}\% \text { Wilted } \\
\text { plants }\end{array}$} & \multirow{2}{*}{$\begin{array}{c}\% \\
\text { Survived } \\
\text { plants }\end{array}$} \\
\hline & $\begin{array}{c}\text { Pre- } \\
\text { emergence }\end{array}$ & $\begin{array}{c}\text { Post- } \\
\text { emergence }\end{array}$ & & \\
\hline Fusarium oxysporum (1) & 5.00 & 33.33 & 26.67 & 35.00 \\
\hline Fusarium oxysporum (2) & 3.33 & 11.67 & 25.00 & 60.00 \\
\hline Fusarium oxysporum (3) & 5.00 & 18.33 & 23.33 & 53.34 \\
\hline F. solani $(1)$ & 23.33 & 26.67 & 0.00 & 50.00 \\
\hline F. solani $(3)$ & 13.33 & 11.67 & 0.00 & 75.00 \\
\hline Macrophomina phaseolina (1) & 40.00 & 26.67 & 0.00 & 33.33 \\
\hline Macrophomina phaseolina (2) & 33.33 & 23.33 & 0.00 & 43.34 \\
\hline Macrophomina phaseolina (3) & 31.67 & 11.67 & 0.00 & 56.66 \\
\hline Rhizoctonia solani $(1)$ & 26.67 & 40.00 & 0.00 & 33.33 \\
\hline Rhizoctonia solani (2) & 18.33 & 33.33 & 0.00 & 48.34 \\
\hline Rhizoctonia solani (3) & 23.33 & 33.33 & 0.00 & 43.34 \\
\hline Pythium sp. (2) & 33.33 & 5.00 & 0.00 & 61.67 \\
\hline Control (without fungus) & 0.00 & 0.00 & 0.00 & 100.00 \\
\hline L.S.D. at 5\% & 1.47 & 3.43 & - & - \\
\hline
\end{tabular}

(1) Beheira governorate isolate.

(2) Ismailia governorate isolate.

(3) Minia governorate isolate.

Evaluation of the essential oil emulsions effect on the mycelial growth of the tested fungi in vitro

Data shown in Table (3) indicate that the different concentrations of marjoram and peppermint oil emulsions significantly inhibited the growth of the tested fungi in comparison with the control. Marjoram and peppermint emulsion oils completely Egypt. J. Phytopathol., Vol. 47, No. 2 (2019) 
inhibited the growth of $F$. oxysporum, F. solani, R. solani and Pythium sp. at $5 \mathrm{ml} / \mathrm{L}$. On the other hand, M. phaseolina was the lowest affected fungus with the tested essential oils. Positive effectiveness of the present essential oils on mycelial growth of the fungi tested might be due to the increase in the permeability of the fungal cell walls as well as inhibition in the fungal detoxificating enzymes of the antifungal oil substances. The essential oils are also capable to affect respiration of the fungal cell (oxygen uptake) and having toxic substances acting as antisporulation compounds (Inouye et al., 1988).

Table (3). Effect of different concentrations of marjoram and peppermint essential oil emulsions on mycelial growth of the isolated fungi.

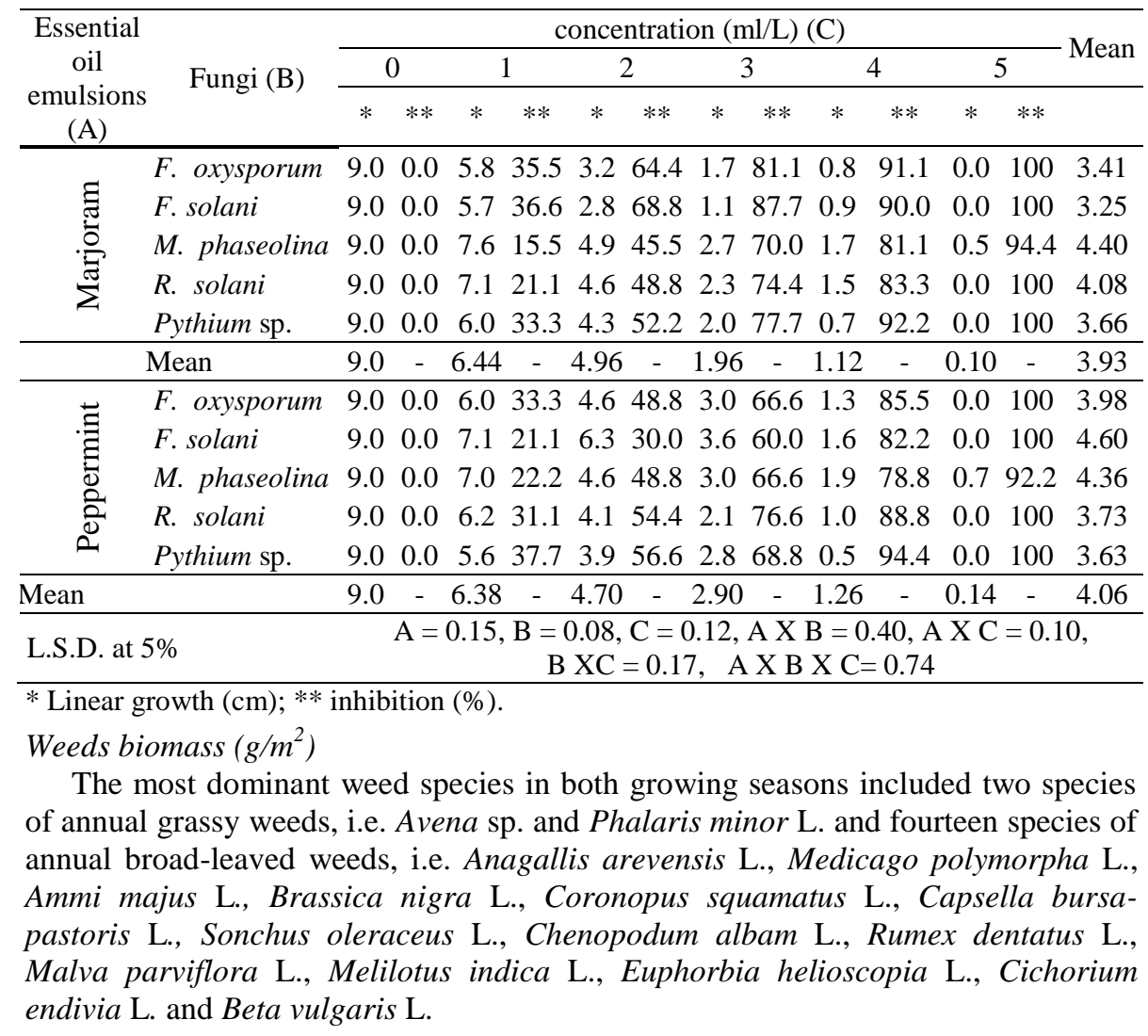

All weed control treatments significantly decreased the dry weight of grassy weeds, broad-leaved weeds and total weeds70 days after sowing as compared to the unweeded control (Table 4). The highest reductions in total dry weight of weeds were obtained with black plastic mulch,being $46.06 \mathrm{~g} / \mathrm{m}^{2}$ and $43.80 \mathrm{~g} / \mathrm{m}^{2}$, followed by 
hoeing, being $51.50 \mathrm{~g} / \mathrm{m}^{2}, 46.20 \mathrm{~g} / \mathrm{m}^{2}$ then cover crop $\left(73.63 \mathrm{~g} / \mathrm{m}^{2}, 64.63 \mathrm{~g} / \mathrm{m}^{2}\right)$ in the first and second growing seasons, respectively compared to unweeded treatment as shown in Table (4).

Table (4). Effect of weed control treatments on biomass of grassy weeds, broadleaved weeds and total weeds during 2017/2018 and 2018/2019 growing seasons.

\begin{tabular}{lcccccc}
\hline \multirow{2}{*}{$\begin{array}{c}\text { Weed control } \\
\text { treatments }\end{array}$} & \multicolumn{6}{c}{ Weed biomass $\left(\mathrm{g} / \mathrm{m}^{2}\right)$} \\
\cline { 2 - 7 } \multicolumn{1}{c}{ Grassy weeds } & Broad-leaved weeds & \multicolumn{2}{c}{ Total weeds } \\
\cline { 2 - 7 } & $1^{\text {st }}$ season & $2^{\text {nd }}$ season & $1^{\text {st }}$ season & $2^{\text {nd }}$ season & $1^{\text {st }}$ season & $2^{\text {nd }}$ season \\
\hline Unweeded control & 329.76 & 316.03 & 117.86 & 96.43 & 447.63 & 412.46 \\
Hoeing & 39.56 & 34.40 & 11.93 & 11.80 & 51.50 & 46.20 \\
Plastic mulch & 35.46 & 29.70 & 10.60 & 14.10 & 46.06 & 43.80 \\
Cover crop & 53.86 & 42.30 & 19.76 & 22.33 & 73.63 & 64.63 \\
\hline L.S.D. at 5\% & 13.54 & 11.41 & 6.33 & 6.26 & 12.11 & 11.10 \\
\hline
\end{tabular}

The effectiveness of plastic mulch in controlling weeds has also been reported by Ricotta and Masiunas (1991) who evaluated black polyethylene mulch and herbicide application for weed control in basil and rosemary plants and mentioned that plastic mulch provided the best weed control within the rows, although some weeds emerged through the holes in the plastic.

Reductions in weed biomass have been reported with subterranean clover living mulch and increased soybean yield by $91 \%$ relative to weedy control plots (Ilnicki and Enache, 1992). Moreover, Chase and Mbuya (2008) reported that weed biomass was lowest with rye and black oat living mulches when used in organic broccoli production. Mulching and cover crops suppress weeds through their physical presence with soil surface by shading, allelopathic activity and blocking the light required for germination of many small-seeded weed species or by competing for water and nutrients (Teasdale and Mohler, 1993).

\section{Field experiment}

\section{Disease incidence}

The most commonly observed wilt disease symptoms in cumin plants were yellowing, browning, and wilting of lower leaves, possibly with some internal vascular discoloration in the stem. Data in Tables (5) and (6) reveal that wilt incidence was significantly affected by different weed control treatments, seed treatment and their interactions. Wilt incidence ranged from $1.3-8.7 \%$ in different weed control treatments during the second growing season.

The highest disease incidence was recorded in the unweeded plots $(8.7 \%$ on the average), while the lowest disease incidence (1.3\%) and the maximum percentage of survived plants $(98.7 \%$ on the average) were recorded in plastic mulched plots (Table, 6). This treatment was closely followed by plots with cover crop which $2.7 \%$ disease incidence on the average in the second growing season.

Egypt. J. Phytopathol., Vol. 47, No. 2 (2019) 
Table (5): Effect of weed control treatments and seed treatment on wilt incidence $(\%)$ and plant survival $(\%)$ during 2017/2018 growing season.

\begin{tabular}{|c|c|c|c|c|c|c|c|c|c|c|}
\hline \multirow{4}{*}{$\begin{array}{l}\text { Seed treatment } \\
\text { (B) }\end{array}$} & \multicolumn{10}{|c|}{ First season $(2017 / 2018)$} \\
\hline & \multicolumn{5}{|c|}{ Wilt incidence $(\%)$} & \multicolumn{5}{|c|}{ Survived plants (\%) } \\
\hline & \multicolumn{10}{|c|}{ Weed control treatments $(\mathrm{A})$} \\
\hline & 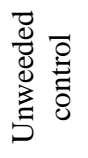 & $\begin{array}{l}\stackrel{\infty}{0} \\
\stackrel{0}{0} \\
\text { 焉 }\end{array}$ & 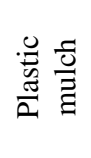 & वे & Mean & 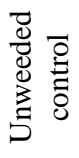 & $\begin{array}{l}\stackrel{\infty}{\Xi} \\
\stackrel{\Xi}{0} \\
\stackrel{\Xi}{ \pm}\end{array}$ & 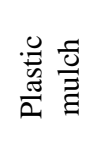 & 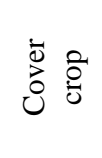 & Mean \\
\hline Control & 16.7 & 13.3 & 10.0 & 10.0 & 12.5 & 83.3 & 86.7 & 90.0 & 90.0 & 87.5 \\
\hline Peppermint oil & 6.7 & 3.3 & 0.0 & 3.3 & 3.3 & 93.3 & 96.7 & 100.0 & 96.7 & 96.7 \\
\hline Marjoram oil & 3.3 & 0.0 & 0.0 & 0.0 & 0.8 & 96.7 & 100.0 & 100.0 & 100.0 & 99.2 \\
\hline Plant Guard & 6.7 & 3.3 & 3.3 & 3.3 & 4.2 & 93.3 & 100.0 & 96.7 & 96.7 & 95.8 \\
\hline Rhizo-N & 6.7 & 0.0 & 3.3 & 3.3 & 3.3 & 93.3 & 96.7 & 96.7 & 96.7 & 96.7 \\
\hline Mean & 8.0 & 4.0 & 3.3 & 4.0 & - & 92.0 & 96.0 & 96.7 & 96.0 & - \\
\hline L.S.D at $5 \%$ & & & $\begin{array}{l}A=0.7 \\
B=0.3 \\
\times B=\end{array}$ & & & & & $\begin{array}{l}\mathrm{A}=1.3 \\
\mathrm{~B}=1.0 \\
\times \mathrm{B}=1\end{array}$ & & \\
\hline
\end{tabular}

Table (6): Effect of weed control treatments and seed treatment on wilt incidence $(\%)$ and plant survival (\%) during 2018/2019 growing season.

\begin{tabular}{|c|c|c|c|c|c|c|c|c|c|c|}
\hline \multirow[b]{4}{*}{$\begin{array}{l}\text { Seed treatment } \\
\text { (B) }\end{array}$} & \multicolumn{10}{|c|}{ Second season $(2018 / 2019)$} \\
\hline & \multicolumn{5}{|c|}{ Wilt incidence $(\%)$} & \multicolumn{5}{|c|}{ Survived plants $(\%)$} \\
\hline & \multicolumn{10}{|c|}{ Weed control treatments $(\mathrm{A})$} \\
\hline & 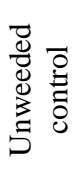 & $\begin{array}{l}\stackrel{\infty}{\Xi} \\
\stackrel{\Xi}{0} \\
\stackrel{0}{I}\end{array}$ & 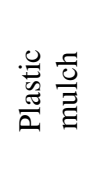 & $\begin{array}{l}00 \\
0 \\
0 \\
0 \\
0 \\
0\end{array}$ & Mean & 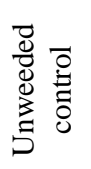 & $\begin{array}{l}\stackrel{\infty}{\Xi} \\
: 0 \\
0 \\
0\end{array}$ & 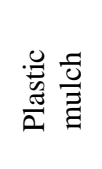 & 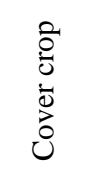 & Mean \\
\hline Control & 16.7 & 10.0 & 6.7 & 6.7 & 10.0 & 83.3 & 90.0 & 93.3 & 93.3 & 90.0 \\
\hline Peppermint oil & 10.0 & 3.3 & 0.0 & 0.0 & 3.3 & 90.0 & 96.7 & 100.0 & 100.0 & 96.7 \\
\hline Marjoram oil & 6.7 & 0.0 & 0.0 & 0.0 & 1.7 & 93.3 & 100.0 & 100.0 & 100.0 & 98.3 \\
\hline Plant Guard & 6.7 & 0.0 & 0.0 & 3.3 & 2.5 & 93.3 & 100.0 & 100.0 & 96.7 & 97.5 \\
\hline Rhizo-N & 3.3 & 3.3 & 0.0 & 3.3 & 2.5 & 96.7 & 96.7 & 100.0 & 96.7 & 97.5 \\
\hline Mean & 8.7 & 3.3 & 1.3 & 2.7 & - & 91.3 & 96.7 & 98.7 & 97.3 & - \\
\hline L.S.D at $5 \%$ & \multicolumn{5}{|c|}{$\begin{array}{c}\mathrm{A}=0.6 \\
\mathrm{~B}=0.3 \\
\mathrm{~A} \times \mathrm{B}=0.7\end{array}$} & \multicolumn{5}{|c|}{$\begin{array}{c}\mathrm{A}=1.1 \\
\mathrm{~B}=1.5 \\
\mathrm{~A} \times \mathrm{B}=2.0\end{array}$} \\
\hline
\end{tabular}


Weed control can play a role in reducing disease incidence which can ultimately reduce fungicide use. Jambhulkar et al. (2012) found that plastic mulching reduced early blight of tomato by hindering the conidial movement. Reducing disease incidence by cover crops also has been reported by several authors. Ristaino et al. (1997) reported that a wheat cover crop reduced Phytophthora blight of peppers due to reduced dispersal of propagules of the causal agent. Moreover, ahairy vetch and Austrian winter pea cover crop reduced fruit rot incidence in tomato plants compared to plants in fallow plots (Nyochembeng et al., 2014).

Similarly, soaking cumin seeds in essential oils of marjoram and peppermint at a concentration of $(5 \mathrm{ml} / \mathrm{L})$ significantly decreased the percentages of wilted plants, as compared to the control. Marjoram essential oil was more effective than peppermint oil in reducing the percentages of disease incidence (Tables 5 and 6). Furthermore, the application of marjoram oil resulted in the highest percentages of survived plant when compared with other treatments during both seasons. These findings are in agreement with an earlier report on similar effects of essential oils on the reduction of wilt and root rot incidence in green beans (El-Mougy et al., 2007).The efficacy of essential oils as antifungal agents is well documented. The major constituents of marjoram essential oil were determined to be cis-sabinene hydrate and terpinene-4ol that comprise more than $60 \%$ of the oil constituents (Gharieb, 2006). Several of these components have been previously tested for their biological activity against a number of fungi. In this respect, Terzi et al.(2007) found that terpinen-4-ol, gammaterpinene and 1,8-cineole, the principal components of Melaleuca alternifolia essential oil had highly inhibitory effect against the mycelial growth of some pathogenic fungi and among the tested compounds, terpinen-4-ol was the most effective one. Hence, it could be suggested that the antifungal activity of marjoram oil is due to the presence of the main component terpinene-4-ol in the oil. Moreover, Edris and Farrag (2003) confirmed the inhibitory effect of menthol (one of the major constituents in peppermint essential oil) on the growth of the fungi Sclerotinia sclerotiorum and Rhizopus stolonifer, and they stated that menthol was the only constituent responsible for the antifungal properties of peppermint essential oil. The antifungal activity might be due to the highly lipophilic nature of terpenes and low molecular weight that leads to disrupting of the cell membrane, causing cell death or inhibiting the sporulation and germination of the fungi (da Silva Bomfim et al., 2015).

The application of Plant Guard and Rhizo-N significantly reduced the incidence of wilt disease (Tables 5 and 6). Rhizo-N was more effective than Plant Guard in reducing the disease incidence resulting in a higher percentage of survived plants during the first season (Table 5). Whereas, the effects of these treatments were similar during the second season. Rhizo-N has proved to be an effective biocontrol agent against a broad range of plant pathogens. Podile and Prakash (1996) showed that groundnut seeds bacterized with $B$. subtilis caused a reduction in the disease incidence of crown rot in infested soil with Aspergillus niger, suggesting a possible Egypt. J. Phytopathol., Vol. 47, No. 2 (2019) 
role of B. subtilis in biological control of A. niger. B. subtilis antagonizes fungal pathogens by producing antifungal peptides that cause lysis of the phytopathogenic fungal cell wall (Gong et al., 2014). Bacillus species are also capable of producing enzymes like chitinase having a very strong lytic activity (Zhao et al., 2014). Disease suppression induced by Trichoderma spp. has been reported by Aghnoom et al. (1999) who mentioned that cumin seeds treated with Trichoderma harzianum T2 isolate, lowered disease incidence caused by $F$. oxysporum f.sp. cumini by $65.4 \%$ and this treatment was found to be more effective than seed treatment with the fungicides. Moreover, Tawfik and Allam (2004) mentioned that the lowest percentage of cumin infection was found in pre-sowing seed treatment with $T$. harzianum. Disease suppression could be due to competition for nutrients. Trichoderma has a superior capacity to mobilize and take up soil nutrients compared to other organisms (Mohiidin et al., 2010).

Additionally, the interactions between weed control treatments and seed treatment were also significant (Tables 5 and 6). Plants were completely free from wilt incidence in all weed control treatments with cumin seeds soaked in marjoram essential oil $(5 \mathrm{ml} / \mathrm{L})$ in both seasons. Also, there was no occurrence of the disease in hoeing and plastic mulch plots with seeds soaked in B. subtilis and peppermint oil in the $1^{\text {st }}$ season.

Furthermore, it has been observed from the results of this study, that the efficacy of marjoram essential oil was similar to the commercial biocides Plant Guard and Rhizo-Nin controlling cumin wilt. Thus, it could be suggested that marjoram essential oil can be formulated to be used for controlling cumin wilt under field conditions.

Vegetative growth parameters and yield of cumin plants

The effect of weed control treatments, seed treatment and their interaction on cumin growth and yield are presented in Tables (7-10). All treatments had positively affected the growth and yield parameters of cumin plants in both seasons. In 2018, the lowest plant height, number of branches/plant, number of umbels/plant and seed yield ( $\mathrm{kg} / \mathrm{fed}$.) were recorded under unweeded control, while the highest plant height and number of branches were obtained by plants grown in plastic mulched plots. However, there was no significant difference between plastic mulch and hoeing treatments (Tables7 and 8). In 2019, hoeing significantly improved seed yield (kg/fed.) and was closely followed by plastic mulch plots. Enhancement of cumin growth and yield under black plastic mulch might be due to the effective control of weeds, which reduced weed competition for light, water and essential nutrients. Similar findings were also reported by some investigators (Ashrafuzzaman et al., 2011 and Pradeep et al., 2017). Ricotta and Masiunas (1991) also reported an increase in fresh and dry weights of basil yield and rosemary in polythene mulched plots than unmulched plots, unlike parsley yield that did not respond to the mulch. Black plastic mulching has been found to have several advantages resulting in 
enhancing performance and growth of plants. These advantages include maintaining high soil water contents thus improving water use efficiency, optimizing soil temperature and suppression of weeds (Bond and Grundy, 2001 and Tarara, 2002).

The obtained results revealed that cumin growth and yield traits in case of cover crop plots was significantly lower than plastic mulch treatment but higher than the unweeded control treatment. This decrease in growth parameters in cumin plants may be due to competition with clover as the living mulch. Previous studies showed that the species, when selected as living mulches do not suppress weeds selectively, but suppress the crop as well; therefore, living mulches must be managed carefully to reduce their competition with the crop. In this respect, Chase and Mbuya (2008) mentioned that black oat, rye, and annual ryegrass as living mulches were effective in inhibiting weed biomass, but interfered with broccoli growth, which resulted in reduction in the yield. Marks (1993) suggested that reduced growth of the main crop might be due to competition for water or some other limited resource, or the mulch may be having an allelopathic effect.

Table (7): Effect of weed control treatments and seed treatment on plant height (cm) of cumin plants during 2017/2018 and 2018/2019 growing seasons.

\begin{tabular}{|c|c|c|c|c|c|c|c|c|c|c|}
\hline \multirow{4}{*}{$\begin{array}{l}\text { Seed treatment } \\
\text { (B) }\end{array}$} & \multicolumn{10}{|c|}{ Plant height $(\mathrm{cm})$} \\
\hline & \multicolumn{5}{|c|}{ First season $(2017 / 2018)$} & \multicolumn{5}{|c|}{ Second season $(2018 / 2019)$} \\
\hline & \multicolumn{10}{|c|}{ Weed control treatments (A) } \\
\hline & 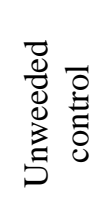 & $\begin{array}{l}\stackrel{\infty}{0} \\
\stackrel{0}{0} \\
0 \\
1\end{array}$ & 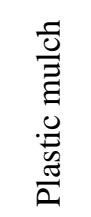 & 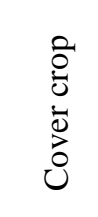 & Mean & 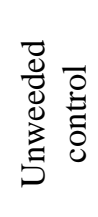 & 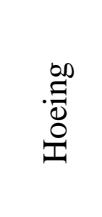 & 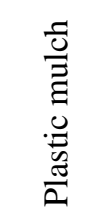 & $\begin{array}{l}\text { Oे' } \\
\dot{0} \\
\dot{0} \\
\overrightarrow{0} \\
0\end{array}$ & Mean \\
\hline Control & 12.11 & 23.22 & 22.72 & 22.11 & 20.04 & 13.05 & 23.61 & 23.61 & 24.44 & 21.17 \\
\hline Peppermint oil & 12.22 & 24.16 & 23.88 & 24.88 & 21.28 & 13.44 & 26.05 & 24.66 & 25.22 & 22.34 \\
\hline Marjoram oil & 13.22 & 25.50 & 25.61 & 25.00 & 22.33 & 14.33 & 26.66 & 26.88 & 26.00 & 23.46 \\
\hline Plant Guard & 12.88 & 24.00 & 24.94 & 25.44 & 21.81 & 14.55 & 24.55 & 25.94 & 25.44 & 22.62 \\
\hline Rhizo-N & 13.11 & 24.61 & 24.66 & 24.06 & 21.61 & 15.27 & 25.94 & 25.11 & 24.77 & 22.77 \\
\hline Mean & 12.70 & 24.32 & 24.36 & 24.29 & - & 14.12 & 25.36 & 25.14 & 25.17 & - \\
\hline \multirow[t]{3}{*}{ L.S.D at $5 \%$} & \multicolumn{5}{|c|}{$\mathrm{A}=0.71$} & \multicolumn{5}{|c|}{$A=0.73$} \\
\hline & \multicolumn{5}{|c|}{$B=0.68$} & \multicolumn{5}{|c|}{$\mathrm{B}=0.52$} \\
\hline & \multicolumn{5}{|c|}{$\mathrm{A} \times \mathrm{B}=1.82$} & \multicolumn{5}{|c|}{$\mathrm{A} \times \mathrm{B}=1.75$} \\
\hline
\end{tabular}

Egypt. J. Phytopathol., Vol. 47, No. 2 (2019) 
Table (8): Effect of weed control treatments and seed treatment on number of branches/plant of cumin plants during 2017/2018 and 2018/2019 growing seasons.

\begin{tabular}{|c|c|c|c|c|c|c|c|c|c|c|}
\hline \multirow[b]{4}{*}{$\begin{array}{l}\text { Seed treatment } \\
\text { (B) }\end{array}$} & \multicolumn{10}{|c|}{ Number of branches/plant } \\
\hline & \multicolumn{5}{|c|}{ First season $(2017 / 2018)$} & \multicolumn{5}{|c|}{ Second season $(2018 / 2019)$} \\
\hline & \multicolumn{10}{|c|}{ Weed control treatments $(\mathrm{A})$} \\
\hline & 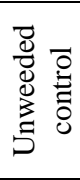 & 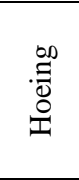 & 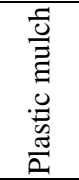 & $\begin{array}{l}\tilde{0} \\
0 \\
\dot{0} \\
\dot{0} \\
0\end{array}$ & Mean & 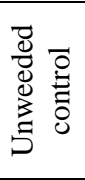 & $\begin{array}{l}\stackrel{00}{\Xi} \\
\stackrel{\Xi}{0} \\
\stackrel{0}{I}\end{array}$ & 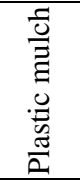 & 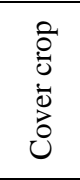 & Mean \\
\hline Control & 3.11 & 5.16 & 7.05 & 4.10 & 4.85 & 3.05 & 5.94 & 6.61 & 5.27 & 5.21 \\
\hline Peppermint oil & 3.55 & 6.66 & 6.21 & 5.99 & 5.60 & 3.77 & 6.72 & 6.94 & 6.27 & 5.92 \\
\hline Marjoram oil & 3.22 & 7.83 & 7.94 & 6.27 & 6.31 & 3.66 & 6.99 & 7.27 & 6.94 & 6.21 \\
\hline Plant Guard & 3.55 & 6.66 & 6.27 & 5.77 & 5.56 & 3.94 & 5.88 & 6.49 & 6.21 & 5.63 \\
\hline Rhizo-N & 3.60 & 7.27 & 7.27 & 6.66 & 6.20 & 4.27 & 6.94 & 7.38 & 6.88 & 6.36 \\
\hline Mean & 3.40 & 6.71 & 6.94 & 5.75 & - & 3.73 & 6.49 & 6.93 & 6.31 & - \\
\hline L.S.D at $5 \%$ & & & $\begin{array}{l}=0 . \\
=0.3 \\
B=0\end{array}$ & & & & & $\begin{array}{l}=0 . \\
=0 . \\
\mathrm{B}=\end{array}$ & & \\
\hline
\end{tabular}

Similarly, seed treatment influenced cumin growth and yield parameters, significant differences in plant height and number of branches/plant were observed among various essential oils or biocontrol agent treatments (Tables7-10). In both years, the highest mean values were obtained with marjoram oil application (Tables 7 and 8), whereas the highest number of umbels/plant and seed yield (kg/fed.) were obtained with Rhizo-N application (Tables 9 and 10). The stimulatory effect of essential oils and bioagents on plant growth has been confirmed by some investigators (Bardia and Rai, 2007; El-Mohamedy and Abd El-Baky, 2008). The beneficial effects of Trichoderma spp. on plant growth has been reported by several authors. Cucumber plants inoculated with $T$. harzianum significantly increased dry weight, shoot length and leaf area and enhanced the availability of $\mathrm{P}$ and Fe to plants (Yedidia et al., 2001). Bacillus subtilis has been widely used for plant growth promotion in a number of ways including its ability to produce phytohormones such as IAA, gibberellins, cytokinins and increase root and shoot cell division and elongation (Idris et al., 2004) and by increasing the availability of N, P, and Fe in the soil (Kim et al., 2011 and Ortíz-Castro et al., 2014), as well as its ability to produce volatile organic compounds which play a significant role in promoting plant growth by regulating the synthesis or metabolism of phytohormones (Tahir et al., 2017). The interactions between weed control treatments and seed treatment on vegetative growth and seed yield were also significant (Tables 7-10). Maximum values were obtained from hoeing and plastic mulch plots with seeds soaked in Rhizo-N or marjoram essential oil in the first and second growing seasons. 
Table (9): Effect of weed control treatments and seed treatment on number of umbels/plant of cumin during 2017/2018 and 2018/2019 growing seasons.

\begin{tabular}{|c|c|c|c|c|c|c|c|c|c|}
\hline \multirow[b]{4}{*}{$\begin{array}{l}\text { Seed treatment } \\
\text { (B) }\end{array}$} & \multicolumn{9}{|c|}{ Number of umbels/plant } \\
\hline & \multicolumn{4}{|c|}{ First season $(2017 / 2018)$} & \multicolumn{5}{|c|}{ Second season $(2018 / 2019)$} \\
\hline & \multicolumn{9}{|c|}{ Weed control treatments $(\mathrm{A})$} \\
\hline & 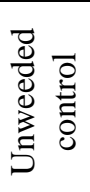 & 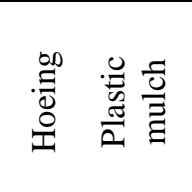 & $\begin{array}{l}0 \\
0 \\
0 \\
0 \\
0 \\
0\end{array}$ & Mean & 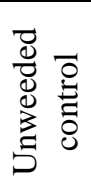 & $\begin{array}{l}\stackrel{\infty}{\Xi} \\
: 0 \\
\stackrel{\Xi}{1}\end{array}$ & 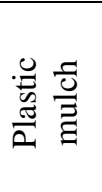 & $\begin{array}{l}0 \\
0 \\
0 \\
\dot{0} \\
0 \\
0\end{array}$ & Mean \\
\hline Control & 4.11 & 17.6616 .271 & 16.27 & 13.57 & 4.94 & 18.38 & 15.88 & 12.88 & 13.02 \\
\hline Peppermint oil & 4.88 & 19.9420 .101 & 15.83 & 15.18 & 4.72 & 18.88 & 20.11 & 14.88 & 14.64 \\
\hline Marjoram oil & 5.44 & 20.2221 .491 & 16.61 & 15.94 & 5.83 & 19.44 & 22.27 & 15.88 & 15.85 \\
\hline Plant Guard & 4.55 & 18.3317 .661 & 19.27 & 14.95 & 5.72 & 17.66 & 17.88 & 15.55 & 14.20 \\
\hline Rhizo-N & 6.83 & 22.0021 .38 & 18.83 & 17.26 & 6.11 & 22.22 & 22.44 & 16.11 & 16.72 \\
\hline Mean & 5.16 & 19.6319 .38 & 17.36 & - & 5.46 & 19.31 & 19.71 & 15.06 & - \\
\hline L.S.D at $5 \%$ & & $\begin{array}{r}\mathrm{A}=1.70 \\
\mathrm{~B}=1.49 \\
\mathrm{~A} \times \mathrm{B}=2 .\end{array}$ & & & & & $\begin{array}{l}\mathrm{A}=1.1 \\
\mathrm{~B}=1.5 \\
\times \mathrm{B}=2 .\end{array}$ & & \\
\hline
\end{tabular}

Table (10): Effect of weed control treatments and seed treatment on seed yield (kg/fed.) of cumin during 2017/2018 and 2018/2019 growing seasons.

\begin{tabular}{|c|c|c|c|c|c|c|c|c|c|c|}
\hline \multirow[b]{4}{*}{$\begin{array}{l}\text { Seed treatment } \\
\text { (B) }\end{array}$} & \multicolumn{10}{|c|}{ Number of umbels/plant } \\
\hline & \multicolumn{5}{|c|}{ First season $(2017 / 2018)$} & \multicolumn{5}{|c|}{ Second season $(2018 / 2019)$} \\
\hline & \multicolumn{10}{|c|}{ Weed control treatments $(\mathrm{A})$} \\
\hline & 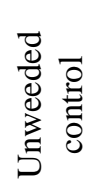 & 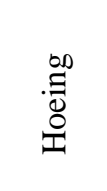 & 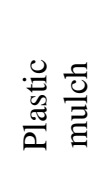 & $\begin{array}{l}0 \\
0 \\
0 \\
\dot{0} \\
0 \\
0\end{array}$ & Mean & 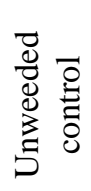 & $\begin{array}{l}\stackrel{\infty}{\Xi} \\
\stackrel{0}{0} \\
\stackrel{0}{1}\end{array}$ & $\frac{\stackrel{0}{E}}{\frac{\vec{E}}{2}}$ & $\begin{array}{l}0 \\
0 \\
0 \\
\dot{0} \\
0 \\
0\end{array}$ & Mean \\
\hline Control & 61.77 & 417.40 & 405.00 & 354.9 & 309.8 & 52.19 & 432.2 & 427.1 & 337.1 & 312.1 \\
\hline Peppermint oil & 64.76 & 426.30 & 421.30 & 340.2 & 313.2 & 73.59 & 442 & 439.8 & 332.6 & 321.9 \\
\hline Marjoram oil & 66.46 & 478.80 & 468.30 & 338.2 & 337.9 & 85.8 & 469.6 & 481.5 & 365.2 & 350.5 \\
\hline Plant Guard & 67.73 & 459.80 & 464.20 & 346.5 & 334.6 & 71.05 & 464.6 & 452.9 & 334.2 & 330.6 \\
\hline Rhizo-N & 64.64 & 481.90 & 490.80 & 339.3 & 344.2 & 81.02 & 474.5 & 454.9 & 375.0 & 346.4 \\
\hline Mean & 65.07 & 452.80 & 449.9 & 343.8 & - & 72.73 & 456.6 & 451.2 & 348.8 & - \\
\hline L.S.D at $5 \%$ & & $\mathrm{Ax}$ & $\begin{array}{l}A=7.80 \\
3=6.16 \\
B=12.7\end{array}$ & & & & & $\begin{aligned} A & =6.4 \\
B & =7.5 \\
x B & =11\end{aligned}$ & & \\
\hline
\end{tabular}

Egypt. J. Phytopathol., Vol. 47, No. 2 (2019) 


\section{Conclusion}

In conclusion, plastic mulching had a positive effect on suppression of weeds, reduced disease incidence of Fusarial wilt and enhanced vegetative growth and yield of cumin plants. In addition, seed treatment with any of the Rhizo-N $(4 \mathrm{ml} / \mathrm{L})$ or marjoram essential oil at a concentration of $5 \mathrm{ml} / \mathrm{L}$ controlled wilt disease and was comparable to, or more effective than that provided by the commercial chemicides, showing potential for being used in controlling the disease. Thus, integration of these methods could provide an approach for the management of the disease in infested cumin fields more effectively.

\section{References}

Aghnoom, R.; Falahati-Rastegar, M. and Jafapour, B. 1999. Comparison of chemical and biological control of cumin wilt (Fusarium oxysporum f. sp, cumini) in laboratory and greenhouse conditions. Iranian J. Agri. Sci., 30: 619630.

Ashrafuzzaman, M.; Abdul Halim, M.; Ismail, M.R., Shahidullah, S.M. and Hossain, M.A. 2011. Effect of plastic mulch on growth and yield of chilli (Capsicum annuит L.) Braz. Arch. Biol. Technol., 54(2): 321-330.

Bardia, P.K. and Rai, P.K. 2007. In vitro and field evaluation of biocontrol agents and fungicides against wilt of cumin caused by Fusarium oxysporum f. sp. cumini. J. of Spices and Aromatic Crops., 16(2): 88-92.

Bhatnagar, K.; Tak, S.K.; Sharma, R.S.; Majumdar, V.L. and Meena, R.L. 2013. Management of cumin wilt caused by Fusarium oxysporum f. sp. cumini through chemical and biological agents. Indian Phytopathol., 66(1): 101-102.

Birla, L.; Naruka, I.S.; Shaktawat, R.P.S and Ajnave S.R. 2016. Integrated weed management in cumin. Indian J. of Weed Sci.,48(1): 102-104.

Bond, W. and Grundy, A.C. 2001. Non-chemical weed management in organic farming systems. Weed Res.,41: 383-405.

Booth, C. 1971. The Genus Fusarium. Commonw. Mycol. Inst., Kew, Surrey, England.

Chase, C.A. and Mbuya, O.S. 2008. Greater interference from living mulches than weeds in organic broccoli production. Weed Technol., 22: 280-285.

da Silva Bomfim, N.; Nakassugi, L.P.; Oliveira J.F.P.; Kohiyama, C.Y.; Mossini, S.A.G.; Grespan, R.; Nerilo, S.B.; Mallmann, C.A.; Filho, B.A.A, and Jr, M.M. 2015. Antifungal activity and inhibition of fumonisin production by Rosmarinus officinalis L. essential oil in Fusarium verticillioides (Sacc.) Nirenberg. Food Chem.,166: 330-336. 
Dange, S.R.S. 1995. Diseases of cumin (Cuminum cyminum L.) and their management. J. of Spices and Aromatic Crops, 4: 57-60.

Domsch, K.H.; Gams, W. and Anderson, T.H. 1980. Compendium of Soil Fungi, Vol. 1\&2, Academic Press, London.

Duke, J.A. 2002. CRC "Handbook of Medicinal Spices", CRC Press, Boca Raton, Florida. Pp.360.

Edris, A.E. and Farrag, E.S. 2003. Antifungal activity of peppermint and sweet basil essential oils and their major aroma constituents on some plant pathogenic fungi from the vapor phase. Nahrung, 47:117-121.

El-Mohamedy, R.S.R. and Abdel El-Baky, M.M.H. 2008. Effect of seed treatment on control of root rot disease and improvement of growth and yield of pea plants. Mid. East. and Russian J. of Plant Sci. and Biotechnol., 2(2), 84-90.

El-Mougy, N.S.; El-Gamal, N.G.; Abdel-Kader, M.M. 2007. Control of wilt and root rot incidence in Phaseolus vulgaris L. by some plant volatile compounds. $J$. of Plant Protec. Res., 47(3): 255-265.

Farrell, K.T. 1985. In: Spices, Condiments and seasonings. The AVI Publishing Co., Inc., Westport, Connecticut, 98-100.

Gharib, F.A. 2006. Effect of salicylic acid on the growth, metabolic activities and oil content of basil and marjoram. Int. J. Agri. Biol., 8(4): 485-492.

Ghoneem, K.M.; Khalil, A.A.; Rashad, E.M.; Ahmed, M.I.M. and Mahmoud, M.S.M. 2019. Granular bioactive formulation of Trichoderma viride and Arbuscular mycorrhizal fungi for biological control of Cumin wilt disease. Egypt. J. of Phytopathol., 47(1): 175-197.

Gong, Q.; Zhang, C.; Lu, F.; Zhao, H.; Bie, X. and Lu, Z. 2014. Identification of bacillomycin D from Bacillus subtilis fmbJ and its inhibition effects against Aspergillus flavus. Food Cont., 36: 8-14.

Hashem, M.; Moharam, A.M.; Zaied, A.A. and Saleh, F.E.M. 2010. Efficacy of essential oils in the control of cumin root rot disease caused by Fusarium spp. Crop Protect., 29: 1111-1117.

Hassan, S.A.M.; Ismail, T.H.; El-Sogheir, G.A. and Amin, F.A. 2014. An economic study of the merits productivity of the most important medicinal and aromatic plants in the provinces of the main production with a focus on Assiut governorate. Assiut J. Agric. Sci., 45(5):184-199.

Hassanin, M.M.H. 2013. Pathological Studies on Root Rot and Wilt of Black Cumin (Nigella sativa) and Their Management in Egypt. Ph.D. Thesis, Fac. Agric., AlAzhar Univ. (Egypt), 137pp.

Egypt. J. Phytopathol., Vol. 47, No. 2 (2019) 
Hassanin, M.M.H.; Abd-El-Sayed, M.A. and Abdallah, M. A. 2017. Antifungal activity of some essential oil emulsions and nanoemulsions against Fusarium oxysporum pathogen affecting cumin and geranium plants. Scientific J. Flowers \& Ornamental Plants, 4(3): 245-258.

Hilal, A.A.; Zayed, A.A. and Harridy, I.M.A. 1993. Fusarium wilt of cumin (Cuminum cyminum L.) in Egypt: Occurrence and chemical control in relation to fruit and volatile oil yield. Proc. $5^{\text {th }}$ Nat. Conf. of Pests\& Dis. Veg. \& Fruits in Egypt, Ismailia, pp. 467-480.

Idris, E.E.; Bochow, H.; Ross, H. and Borriss, R. 2004. Use of Bacillus subtilis as biocontrol agent. VI. Phytohormone like action of culture filtrates prepared from plant growth promoting Bacillus amyloliquefaciens FZB24, FZB42, FZB45 and Bacillus subtilis FZB37. J. of Plant Dis. and Protect., 111(6); 583-597.

Ilnicki, R.D. and Enache, A.J. 1992. Subterranean clover living mulch, an alternative method of weed control. Agric. Ecosys. Environ. 40: 249-264.

Inouye, S.; Watanable, M.; Nishiyama, Y.; Takeo, K.; Akao, M. and Yamaguchi, H. 1988. Antisporulation and respiration effects of essential oils on filamentous fungi. Mycoses, 41: 403-410.

Jambhulkar, P.P.; Meghwal, M.L. and Kalyan, R.K. 2012. Efficacy of plastic mulching, marigold intercropping and fungicidal spray against early blight of tomato caused by Alternaria solani. The Bioscan., 7(2): 365-368.

Khare, M.N.; Tiwari, S.P. and Sharma, Y.K. 2014. Disease problems in the cultivation of Cumin (Cuminum cyminum L.) II. Caraway (Carum carvi L.) and their management leading to the production of high-quality pathogen free seed. Inter. J. Seed Spices., 4(1): 1-8.

Kim, Y.C.; Leveau, J.; Gardener, B.B.M.; Pierson, E.A.; Pierson, L.S. and Ryu, C.M. 2011. The multifactorial basis for plant health promotion by plant associated bacteria. App. Environ. Microbiol., 77: 1548-1555.

Marks, M.J. 1993. Preliminary results of an evaluation of alternatives to the use of herbicides in orchards. Proceedings Brighton Crop Protection Conference Weeds, Brighton, UK, 461-466.

Mohammadi, G.R.; Mozafari1, S.; Najaphy, A. and Ghobadi, M.E. 2012. Corn (Zea mays L.) seed vigour and quality as influenced by weed interference and living mulch. Adv. in Environ. Biol., 6(3): 1026-1031.

Mohiidin, F.A.; Khan, M.R.; Khan, S.M. and Bhat, B.H. 2010. Why Trichoderma is considered super hero (super fungus) against the evil parasites? Plant Pathol. J., 9(3): 92-102. 
Nada, M.G.A.; Imarah, D.A. and Halawa, A.E.A. 2014. Efficiency of some silicon sources for controlling damping-off of coriander (Coriandrum sativum L.) in Egypt. Egypt. J. Phytopathol., 42(2): 73-90.

Niternik, P. and Vandler, A.J. 1981. Monograph of the Genus Pythium. Studies in Mycology, No. 21, Central Burea Voor Schimmel Cultures, Baarn, Netherland. Pp.242.

Nyochembeng, L.M.; Regine N.M.; Mentreddy, S.R. and Mayalagu, G. 2014. Cover crop, reflective polyethylene mulch and biofungicide effects on yield and management of diseases in field-grown organic tomato. J. of Agric. Sci., 6(12): 265-275.

Ortíz-Castro, R.; Contreras-Cornejo, H.A.; Macías-Rodríguez, L., and López-Bucio, J. 2014. The role of microbial signals in plant growth and development. Plant Signal. Behav. 4: 701-712.

Parthasarathy, V.A.; Chempakam, B. and Zachariah, T.J. 2008. Chemistry of spices. CAB International, 211-226.

Podile, A.R. and Prakash, A.P. 1996. Lysis and biological control of Aspergillus niger with Bacillus subtitles A. F1. Microbiology, 42: 533-538.

Pradeep, R.; Sreenivas, G. and Leela Rani, P. 2017. Impact of sustainable weed management practices on growth, phenology and yield of rabi grain maize (Zea mays L.) Int. J. Curr. Microbiol. App. Sci., 6(7): 701-710.

Ricotta, J.A. and Masiunas, J.B. 1991. The effects of black plastic mulch and weed control strategies on herb yield. Hortscience, 26(5): 539-541.

Ristaino, J.B.; Parra, G. and Campbell, C.L. 1997. Suppression of Phytophthora blight in bell pepper by a no-till wheat cover crop. Phytopathology, 87: 242-249.

Shujuan, L.; Rong, C.X. and Bo, Y.H. 2012. Identification and isolation of root rot pathogen of Cuminum cymium. Acta Agric. Zhajian., 24: 481-485.

Singh, B.K.; Singh, V.P.; Srivastava, S.; Pandey, A.K. and Shukla, D.N. 2017. Influence of soil properties on wilt incidence of watermelon, tomato, and marigold. Ann. Res. \& Rev. in Biol., 19(5): 1-6.

Snedecor, G.W. and Cochran, G.W. 1980. "Statistical Methods". $7^{\text {th }}$ Ed, Iowa State Univ. Press, Ames, USA. 570 PP.

Tahir, H.A.S.; Gu, Q.; Wu, H.; Raza, W.; Hanif, A.; Wu, L.; Colman, M.V. and Gao, X. 2017. Plant growth promotion by volatile organic compounds produced by Bacillus subtilis SYST2. Front. Microbiol. 8: 171.

Tarara, J.M. 2000. Microclimate modification with plastic mulch. Hortscience, 3(5): 169-180.

Egypt. J. Phytopathol., Vol. 47, No. 2 (2019) 
Tawfik, A.A. and Allam, A.D.A. 2004. Improving cumin production under soil infestation with fusarium wilt pathogen: I-screening of biocontrol agents. Ass. Univ. Bull. Environ. Res., 7(2): 35-45.

Teasdale, J.R. and Mohler, C.L. 1993. Light transmittance, soil temperature, and soil moisture under residue of hairy vetch and rye. Agron. J., 85: 673-680.

Teasdale, J.R. and Mohler, C.L. 2000. The quantitative relationship between weed emergence and the physical properties of mulches. Weed Sci., 48: 385-392.

Terzi, V.; Morcia, C.; Faccioli, P.; Valè, G.; Tacconi, G. and Malnati, M. 2007. In vitro antifungal activity of the tea tree (Melaleuca alternifolia) essential oil and its major components against plant pathogens. Lett. in App. Microbiol., 44(6): 613-618.

Topps, J.H. and Wain, R.L. 1957. Investigations on fungicides: III. The fungitoxicity of 3- and 5-alkylsalicylanilides and parachloroanilides. Ann. Appl. Biol., 45(3): 506-511.

Waller, J.M.; Lenne, J.M. and Waller, S.J. 2002. Plant Pathologist's Pocketbook. $3^{\text {rd }}$ ed. CABI Publishing, New York. pp. 27.

Yedidia, I.; Srivastva, A.K.; Kapulnik, Y. and Chet, I. 2001. Effect of Trichoderma harzianum on microelement concentrations and increased growth of cucumber plants. Plant and Soil, 235(2): 235-242.

Zhao, Y.; Selvaraj, J.N.; Xing, F.; Zhou, L.; Wang, Y.; Song, H.; Tan, X.; Sun, L.; Sangare, L.; Folly, Y.M.E. and Liu, Y. 2014. Antagonistic Action of Bacillus subtilis Strain SG6 on Fusarium graminearum. PLoS ONE 9(3): e92486.

Corresponding author: Hassanin, M.M.H.

E-mail: Eng_Mahmoud_1978@yahoo.com

(Received 25/08/2019;

in revised form 08/09/2019) 


\section{تقييم بعض طرق مقاومة الحثائش والأمراض الفطرية

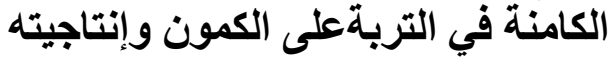 منى عبد المنعم عبد الله' ، محمود عحمل حسانين حسانين ' ، أحمد مصطفى أحمد حسانين".

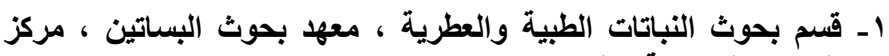

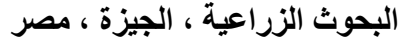

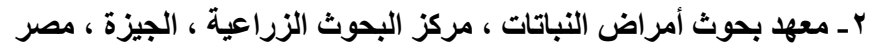

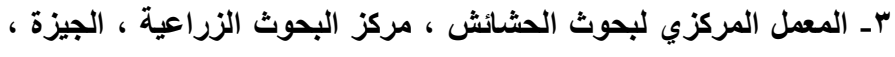

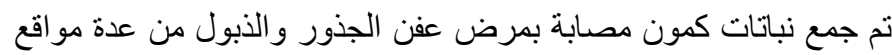

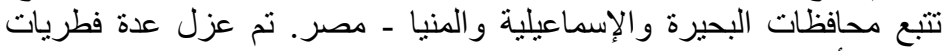

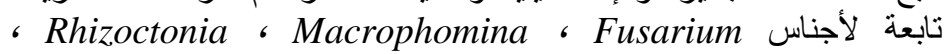
من النباتات المصابة واختبرت قدرتها المرضية في إصابة الكمون. Pythium

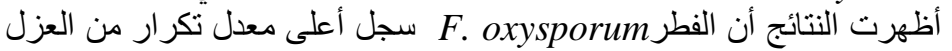

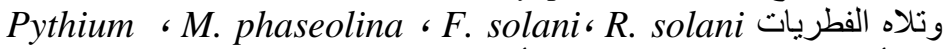

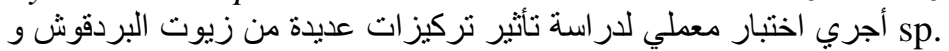

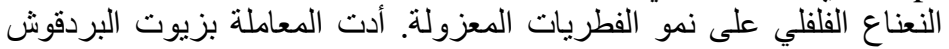

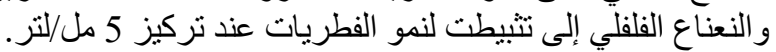

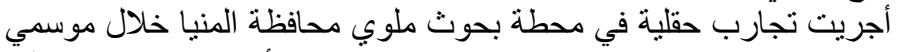

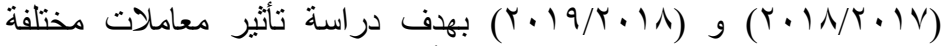

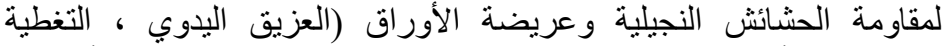

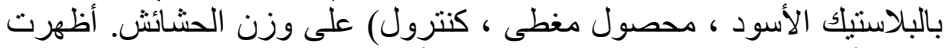

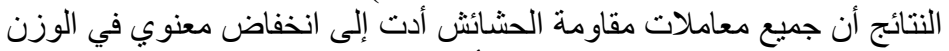

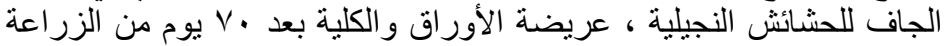

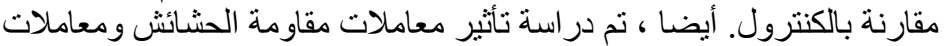

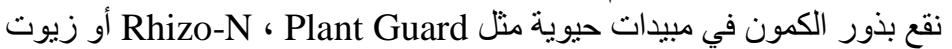

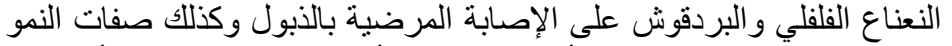

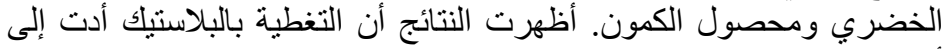

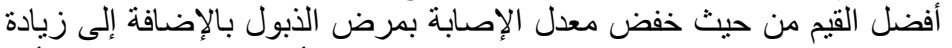

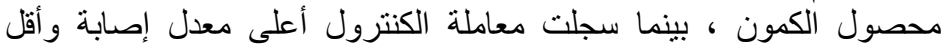

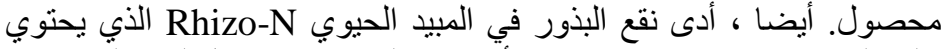

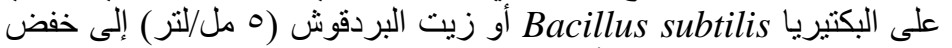

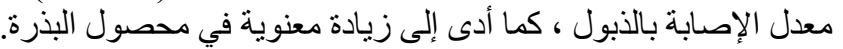

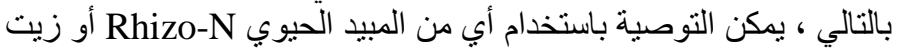

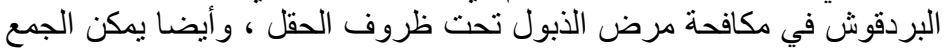

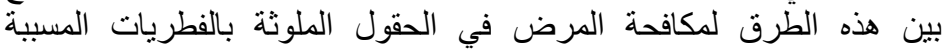

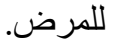

Egypt. J. Phytopathol., Vol. 47, No. 2 (2019) 